\title{
Effect of Nitrogen and Plant Growth Regulators on Growth and Yield of Ajwain (Trachyspermum ammi L. Sprague)
}

\author{
Sheeshpal Choudhary ${ }^{1 *}$, A.C. Shivran", Raja Ram Choudhary ${ }^{2}$, \\ Rajveer Singh $^{1}$ and Shiv Prasad Daroga ${ }^{3}$ \\ ${ }^{1}$ Department of Agronomy, SKN College of Agriculture, SKN Agricultural University, \\ Jobner, Rajasthan-303 329, India \\ ${ }^{2}$ SKN Agricultural University, Jobner, Rajasthan-303 329, India \\ ${ }^{3}$ Junagadh Agricultural University, Junagadh, Gujarat -362 001, India \\ *Corresponding author
}

\begin{tabular}{|c|c|}
\hline & A B S T R A C T \\
\hline & \multirow{6}{*}{ 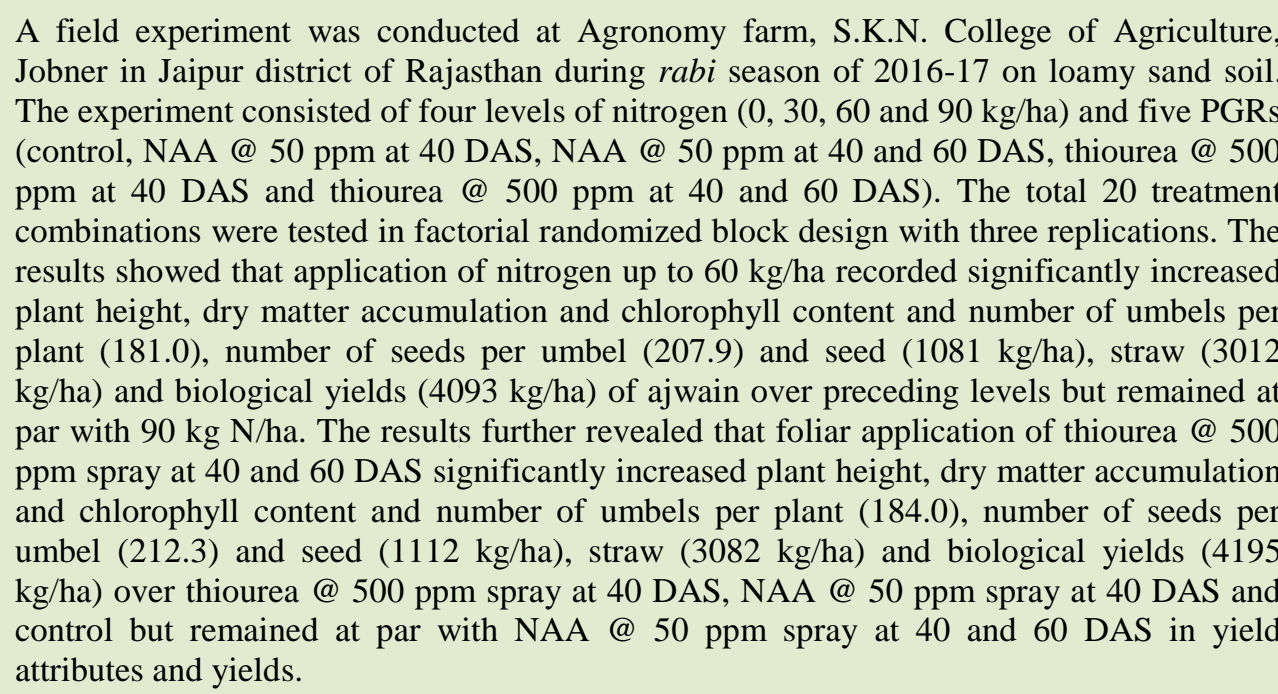 } \\
\hline & \\
\hline $\begin{array}{l}\text { Ajwain, Nitrogen, } \\
\text { PGRs, Growth and } \\
\text { Yield. }\end{array}$ & \\
\hline Article Info & \\
\hline $\begin{array}{l}\text { Accepted: } \\
\text { 07 October } 2017 \\
\text { Available Online: } \\
\text { 10 December } 2017\end{array}$ & \\
\hline & \\
\hline
\end{tabular}

\section{Introduction}

The ajwain (Trachyspermum ammi L., 2n $=18$ ) belonging to the family Apiaceae (Umbelliferae) is an important seed spices. The ajwain is Indigenous to India and Egypt (Sayre, 2001). Ajwain is a cross-pollinated, aromatic and annual herbaceous plant. The flowers are protandrous and cross-pollination occurs through insects. The seed contain 3 to $4 \%$ volatile oil depending on the genotype or botanical type. Besides volatile oil, the seeds contain about $8.9 \%$ moisture, $15.4 \%$ protein, $18.1 \%$ fat, $38.6 \%$ carbohydrate, $11.9 \%$ crude fiber and $7.1 \%$ minerals. The important minerals are calcium, phosphorus, iron, sodium and potassium. While major vitamins found are thiamine, riboflavin, nicotinic acid and carotene (Pruthi, 2001). In India, during the year 2015-16, area under the ajwain crop 
is 24010 ha and production is 17180 tonnes (Anonymous, 2015-16a). In Rajasthan it is cultivated in the districts of Chittorgarh, Udaipur, Rajsamand, Bhilwara, Kota and Jhalawar covering an area of 11058 ha with production and productivity of 4672 tonnes and $401 \mathrm{~kg} / \mathrm{ha}$, respectively (Anonymous, 2015-16b).

\section{Materials and Methods}

The experiment was conducted on plot No. A3 at Agronomy farm, S.K.N. College of Agriculture, Jobner (Rajasthan). Geographically, Jobner is situated $45 \mathrm{~km}$ away from Jaipur in western side at $26^{0} 05^{\prime}$ North latitude, $75^{\circ} 20^{\prime}$ East longitude and at an altitude of 427 metres above mean sea level in Jaipur district of Rajasthan. The region falls under agro-climatic zone-IIIa (Semi-arid eastern plain zone).

The soil of the experimental field was loamy sand in texture with low in organic carbon $(0.14 \%)$, low in available nitrogen (130.0 $\mathrm{kg} / \mathrm{ha}$ ), medium in available phosphorus (18.9 $\mathrm{kg} / \mathrm{ha})$ and potassium (175.6 kg/ha) and slightly alkaline in reaction with $\mathrm{pH} 8.2$.

\section{Results and Discussion}

\section{Effect of nitrogen}

A perusal of data (Table 1 and 2) indicated that nitrogen fertilization did not cause any significant variation in plant height at $35 \mathrm{DAS}$ stage. Application of nitrogen upto $30 \mathrm{~kg} / \mathrm{ha}$ significantly increased in plant height at 70 DAS over control. However, at later stages of crop growth, dry matter accumulation at 70 DAS, 105 DAS and at harvest stages and chlorophyll content significant increase was observed upto $60 \mathrm{~kg} / \mathrm{ha}$ over $30 \mathrm{~kg} \mathrm{~N} / \mathrm{ha}$ and control, respectively. Further increase in its level to $90 \mathrm{~kg} / \mathrm{ha}$ could not enhance the plant height, dry matter accumulation and chlorophyll content upto the level of significance over preceding levels. The application of nitrogen upto $60 \mathrm{~kg} / \mathrm{ha}$ recorded that significantly higher number of umbels per plant (181.0), number of seeds per umbel (207.9) and seed (1081 kg/ha), straw (3012 kg/ha) and biological yields (4093 $\mathrm{kg} / \mathrm{ha}$ ) of ajwain over $30 \mathrm{~kg} / \mathrm{ha}$ and control, but remained at par with $90 \mathrm{~kg} \mathrm{~N} / \mathrm{ha}$.

Application of $30 \mathrm{~kg} \quad \mathrm{~N} / \mathrm{ha}$ recorded significantly higher test weight $(1.47 \mathrm{~g})$ in comparison to control. Further increase in its level to 60 and $90 \mathrm{~kg} \mathrm{~N} / \mathrm{ha}$ though, maximized the test weight 1.55 and $1.57 \mathrm{~g}$, but the difference was not significant.

This might be associated with the corresponding increase in growth attributes characters viz., plant height and dry matter accumulation because of improved nutritional environment in root zone as well as in the plant system leading to higher plant metabolism and photosynthetic activity.

Since, increased the number of umbels per plant, number of seeds per umbel and test weight, biological yield is the sum of seed and straw yields, the improvement in the parameters as discussed above enhanced the biological yield significantly due to nitrogen fertilization. Results of the present investigation corroborate the results of Nath et al., (2008), Naruka et al., (2012) and Muvel et al., (2015) in ajwain.

\section{Effect of plant growth regulators}

A perusal of data (Table 1 and 2) further indicated that PGRs failed to effect the plant height significantly at 35 DAS, however, at later stages of crop growth the plant height was significantly affected. At 70 DAS, PGRs significantly increased the plant height of ajwain over control while remained at par to each other. 
Int.J.Curr.Microbiol.App.Sci (2017) 6(12): 396-400

Table.1 Effect of nitrogen and plant growth regulators on growth parameters of ajwain

\begin{tabular}{|c|c|c|c|c|c|c|c|c|c|}
\hline \multirow[t]{2}{*}{ Treatment } & \multicolumn{4}{|c|}{ Plant height (cm) } & \multicolumn{4}{|c|}{$\begin{array}{l}\text { Dry matter accumulation per metre row length } \\
(\mathrm{g})\end{array}$} & \multirow[t]{2}{*}{$\begin{array}{c}\text { Chlorophyll } \\
\text { content }(\mathrm{mg} / \mathrm{g})\end{array}$} \\
\hline & $\begin{array}{c}35 \\
\text { DAS } \\
\end{array}$ & 70 DAS & $\begin{array}{c}105 \\
\text { DAS }\end{array}$ & $\begin{array}{c}\text { At } \\
\text { harvest }\end{array}$ & 35 DAS & 70 DAS & 105 DAS & At harvest & \\
\hline \multicolumn{10}{|l|}{ Nitrogen level (kg/ha) } \\
\hline 0 & 7.70 & 28.40 & 53.40 & 84.20 & 1.02 & 3.40 & 74.20 & 143.21 & 1.54 \\
\hline 30 & 8.10 & 37.50 & 69.20 & 101.10 & 1.04 & 4.30 & 91.60 & 162.54 & 1.70 \\
\hline 60 & 8.30 & 38.80 & 78.30 & 111.40 & 1.08 & 5.12 & 104.40 & 176.10 & 1.84 \\
\hline 90 & 8.20 & 39.10 & 81.10 & 116.20 & 1.11 & 5.20 & 109.10 & 181.40 & 1.91 \\
\hline $\mathrm{SEm} \pm$ & 0.20 & 0.90 & 1.83 & 2.65 & 0.03 & 0.12 & 2.45 & 4.22 & 0.04 \\
\hline $\mathrm{CD}(\overline{\mathrm{P}}=0.05)$ & NS & 2.58 & 5.24 & 7.58 & NS & 0.33 & 7.01 & 12.07 & 0.13 \\
\hline \multicolumn{10}{|l|}{ Plant growth regulators } \\
\hline Control & 8.11 & 31.03 & 56.78 & 84.58 & 1.08 & 3.81 & 80.29 & 140.37 & 1.52 \\
\hline NAA @ 50 ppm spray at 40 DAS & 8.08 & 36.23 & 68.88 & 99.99 & 1.05 & 4.41 & 92.49 & 161.57 & 1.69 \\
\hline NAA@50 ppm spray at 40 and 60 DAS & 8.25 & 37.40 & 77.08 & 111.17 & 1.02 & 4.81 & 101.99 & 177.17 & 1.84 \\
\hline Thiourea@500 ppm spray at 40 DAS & 7.68 & 36.86 & 69.18 & 103.47 & 1.07 & 4.51 & 94.59 & 165.37 & 1.76 \\
\hline Thiourea @ 500 ppm spray at 40 and 60 DAS & 8.27 & 38.23 & 80.58 & 116.90 & 1.10 & 5.01 & 104.79 & 184.58 & 1.92 \\
\hline $\mathrm{SEm} \pm$ & 0.22 & 1.01 & 2.05 & 2.96 & 0.03 & 0.13 & 2.74 & 4.71 & 0.05 \\
\hline $\mathrm{CD}(\overline{\mathrm{P}}=0.05)$ & NS & 2.88 & 5.86 & 8.47 & NS & 0.37 & 7.83 & 13.49 & 0.14 \\
\hline
\end{tabular}

DAS, Days after sowing; NAA, naphthalene acetic acid; ppm, parts per million

Table.2 Effect of nitrogen and plant growth regulators on yield attributes and yield of ajwain

\begin{tabular}{|c|c|c|c|c|c|c|c|}
\hline \multirow[t]{2}{*}{ Treatment } & \multirow{2}{*}{$\begin{array}{c}\text { Umbels per } \\
\text { plant }\end{array}$} & \multirow{2}{*}{$\begin{array}{c}\text { Seeds per } \\
\text { umbel }\end{array}$} & \multirow[t]{2}{*}{ Test weight (g) } & \multicolumn{3}{|c|}{ Yield (kg/ha) } & \multirow[t]{2}{*}{ Harvest index (\%) } \\
\hline & & & & Seed & Straw & Biological & \\
\hline \multicolumn{8}{|l|}{ Nitrogen level (kg/ha) } \\
\hline 0 & 129.00 & 161.00 & 1.27 & 842 & 2420 & 3262 & 25.79 \\
\hline 30 & 162.00 & 193.60 & 1.47 & 975 & 2745 & 3720 & 26.18 \\
\hline 60 & 181.00 & 207.95 & 1.55 & 1081 & 3012 & 4093 & 26.38 \\
\hline 90 & 189.00 & 214.00 & 1.57 & 1111 & 3112 & 4223 & 26.28 \\
\hline $\mathrm{SEm} \pm$ & 4.24 & 4.91 & 0.04 & 25 & 69 & 94 & 0.64 \\
\hline $\mathrm{CD}(\overline{\mathrm{P}}=0.05)$ & 12.13 & 14.06 & 0.11 & 70 & 197 & 269 & NS \\
\hline \multicolumn{8}{|l|}{ Plant growth regulators } \\
\hline Control & 137.00 & 165.45 & 1.28 & 846 & 2457 & 3304 & 25.60 \\
\hline NAA @ 50 ppm spray at 40 DAS & 161.25 & 190.70 & 1.46 & 975 & 2759 & 3734 & 26.10 \\
\hline NAA@ @ 50 ppm spray at 40 and 60 DAS & 178.60 & 207.85 & 1.53 & 1084 & 3036 & 4120 & 26.30 \\
\hline Thiourea @ 500 ppm spray at 40 DAS & 165.39 & 194.40 & 1.49 & 992 & 2778 & 3771 & 26.30 \\
\hline Thiourea @ 500 ppm spray at 40 and 60 DAS & 184.00 & 212.30 & 1.57 & 1112 & 3082 & 4195 & 26.50 \\
\hline $\mathrm{SEm} \pm$ & 4.74 & 5.49 & 0.04 & 27 & 77 & 105 & 0.72 \\
\hline $\mathrm{CD}(\overline{\mathrm{P}}=0.05)$ & 13.56 & 15.72 & 0.12 & 79 & 220 & 300 & NS \\
\hline
\end{tabular}

DAS, Days after sowing; NAA, naphthalene acetic acid; ppm, parts per million 
Application of thiourea @ 500 ppm spray at 40 and 60 DAS, being at par to NAA @ 50 ppm spray at 40 and 60 DAS, significantly increased the plant height at 105 DAS and at harvest, dry matter accumulation at 70 DAS, 105 DAS and harvest stage and chlorophyll content over thiourea @ 500 ppm spray at 40 DAS, NAA@50 ppm spray at 40 DAS and control. Application of thiourea @ 500 ppm spray at 40 and 60 DAS, being at par to NAA @ 50 ppm spray at 40 and 60 DAS, significantly higher number of umbels per plant (184.0), number of seeds per umbel (212.30) and seed (1112 kg/ha), straw (3082 $\mathrm{kg} / \mathrm{ha}$ ) and biological yields (4195 kg/ha) over thiourea@500 ppm spray at 40 DAS, NAA @ 50 ppm spray at 40 DAS and control. Application of PGRs significantly increased test weight of ajwain over control, however all PGRs remained at par to each other. Thiourea treated crop showed more leaf area available for photosynthate translocation towards sink. This might have been due to improved phloem loading of assimilates under the influence of thiourea spray, most probably on account of $\mathrm{SH}$-group present in thiourea molecules. The SH-group stimulated the photosynthetic carbon fixation mechanism and hence, foliar spray of thiourea might have increased the plant height, dry matter accumulation and chlorophyll content, which ultimately resulted in higher growth of ajwain. Similar results were also reported by Solanki and Sahu (2007) in clusterbean and Meena (2011) in coriander. The increase in yield attributes and yields obtained with thiourea application was most probably due to increased crop photosynthesis favoured by both improved photosynthetic efficiency and source to sink relationship. Similar response with foliar spray of thiourea was also recorded by Balai and Keshwa (2010) and Bochalia et al., (2011) in fenugreek.

Based on the above findings it is concluded that application of @ 500 ppm thiourea as foliar spray twice at 40 and 60 DAS and application of nitrogen fertilization at 60 $\mathrm{kg} / \mathrm{ha}$ is recommended as these treatments fetched significantly higher plant height, dry matter accumulation, chlorophyll content, number of umbels per plant, number of seeds per umbel, seed yield, straw yield and biological yield.

\section{References}

Anonymous, 2015-16a. Vital Agricultural Statistics. Published by Spices Board India, Ministry of Commerce \& Industry, Government of India.

Anonymous, 2015-16b. Vital Agriculture Statistics. Directorate of Agriculture, Pant Krishi Bhawan, Jaipur (Rajasthan).

Balai, L.R. and Keshwa, G.L. 2010. Effect of thiourea on yield and economics of coriander (Coriandrum sativum L.) varieties under normal and late sowing conditions. Journal of Progressive Agriculture 1(1): 52-55.

Bochalia, G.C., Tiwari, R.C., Ram, B., Kantwa, S.R. and Choudhari, A.C. 2011. Response of fenugreek (Trigonella foenum-graecum L.) genotypes to planting geometry, agrochemicals and sulphur levels. Indian Journal of Agronomy 56(3): 273-279.

Meena, S.K. 2011. Effect of Plant Growth Regulators and Sulphur on Productivity of Coriander (Coriandrum sativum L.). M.Sc. (Ag.) Thesis, Swami Keshwanand Rajasthan Agricultural University, Bikaner.

Muvel, R., Naruka, I.S., Chundawat, R.S., Shaktawat, R.P.S., Rathore, S.S. and Verma, R. 2015. Production, productivity and quality of ajwain (Trachyspermum ammi L. Sprague) as affected by plant geometry and fertilizer levels International Journal Seed Spices 5(2): 32-37.

Naruka, I.S., Singh, P.P., Megha Barde and 
S.S. Rathore 2012. Effect of spacing and nitrogen level on growth, yield and quality of ajwain (Trachyspermum ammi L. Sprague). International Journal Seed Spices 2(1): 12-17.

Nath, P., Jaiswal, R.C., Verma, R.B. and Yadav, G.C. 2008. Effect of date of sowing, nitrogen levels and spacing on growth and yield of ajwain (Trachyspermum ammi L. Sprague). Journal of Spices and Aromatic crops 17(1): 1-4.

Pruthi, J.S. 2001. Minor spices and condiments, Crop management and post-harvest technology. Published by publication and Information Division, ICAR, Krishi Anusandhan Bhavan, Pusa, New Delhi-110012, pp. 124-133. Sayre, J.K. 2001. Ancient herbs and modern herbs. Bottlebrush Press, San Carlos, California, USA, pp 14.

Solanki, N.S. and Sahu, M.P. 2007. Productivity and P- use efficiency of clusterbean (Cyamopsis tetragonoloba) as influenced by bioregulators and phosphorus. Indian journal of Agronomy 52(2): 143-147.

\section{How to cite this article:}

Sheeshpal Choudhary, A.C. Shivran, Raja Ram Choudhary, Rajveer Singh and Shiv Prasad Daroga. 2017. Effect of Nitrogen and Plant Growth Regulators on Growth and Yield of Ajwain (Trachyspermum ammi L. Sprague). Int.J.Curr.Microbiol.App.Sci. 6(12): 396-400. doi: https://doi.org/10.20546/ijcmas.2017.612.047 